\title{
Thermal behaviour of Norway spruce and European beech in and between the principal anatomical directions
}

\author{
Journal Article \\ Author(s): \\ Sonderegger, Walter; Hering, Stefan; Niemz, Peter \\ Publication date: \\ 2011-05 \\ Permanent link: \\ https://doi.org/10.3929/ethz-b-000036155
}

Rights / license:

In Copyright - Non-Commercial Use Permitted

Originally published in:

Holzforschung 65(3), https://doi.org/10.1515/HF.2011.036 


\section{Thermal behaviour of Norway spruce and European beech in and between the principal anatomical directions}

\author{
Walter Sonderegger*, Stefan Hering and Peter \\ Niemz \\ Department of Civil, Environmental and Geomatic \\ Engineering, Institute for Building Materials, ETH Zurich, \\ Zurich, Switzerland \\ * Corresponding author. \\ Department of Civil, Environmental and Geomatic Engineering, \\ Institute for Building Materials, ETH Zurich, 8093 Zurich, \\ Switzerland \\ Phone: +41-44-632-6924 \\ Fax: +41-44-632-1174 \\ E-mail: wsonderegger@ethz.ch
}

\begin{abstract}
Thermal conductivity (ThCond), thermal diffusivity and heat capacity of Norway spruce (Picea abies [L.] Karst.) and European beech (Fagus sylvatica L.) have been determined for all principal directions - radial (R), tangential $(\mathrm{T})$ and longitudinal (L) - depending on the moisture content (MC) and ThCond was additionally measured in $15^{\circ}$ steps between these directions. The ThCond was determined in a guarded hot plate apparatus. For determining thermal diffusivity and heat capacity, the same apparatus was supplemented with thermocouples and the temperature evolution was evaluated numerically by a partial differential equation. The results show expectedly that ThCond increases with increasing MC, whereby the highest increment was observed in $\mathrm{T}$ and the lowest in $\mathrm{L}$ direction. ThCond is higher for beech than for spruce in all anatomical directions and the conductivity for both species is more than twice as high in L direction than perpendicular to grain. The highest ThCond is found for beech at a grain angle of approximately $15^{\circ}$. The lowest ThCond shows spruce at an angle of approximately $60^{\circ}$ between $\mathrm{T}$ and $\mathrm{R}$ direction. Thermal diffusivity is similar for both species and decreases with increasing MC. Its differences with regard to the anatomical directions correlate with those of the ThCond values. Heat capacity is lower for beech than for spruce and shows a clear increase with increasing MC.
\end{abstract}

Keywords: beech; heat capacity; moisture content; spruce; thermal conductivity; thermal diffusivity.

\section{Introduction}

Accurate knowledge of thermal properties of wood attracts great interest in the wood industry in application fields such as drying, thermal treatment, steaming and hot gluing. Knowledge in this regard helps optimising the process tech- nology and is becoming increasingly essential in building physics for modelling energy-efficient timber constructions. Thermal conductivity (ThCond), thermal diffusivity and heat capacity are the most important parameters necessary to accurately simulate the thermal behaviour of wood. As wood is an anisotropic material, the first two parameters depend strongly on the anatomical direction and are approximately $3 \%$ to $20 \%$ higher in the radial than in the tangential direction. Moreover, they are in the longitudinal direction approximately 1.5 to 2.75 times higher than perpendicular to the grain. By contrast, the heat capacity is a material-immanent parameter independent of the anisotropic structure and has similar values for all wood species. All three parameters are strongly influenced by temperature and moisture (Kühlmann 1962; Kollmann and Côté 1968; Steinhagen 1977).

The three parameters have the following relationship (Kollmann and Côté 1968):

$\alpha=\frac{\lambda}{c \cdot \rho}$

where $\alpha$ is the thermal diffusivity $\left(\mathrm{m}^{2} \mathrm{~s}^{-1}\right), \lambda$ the ThCond (W m $\left.\mathrm{m}^{-1} \mathrm{~K}^{-1}\right), c$ the heat capacity $\left(\mathrm{J} \mathrm{kg}^{-1} \mathrm{~K}^{-1}\right)$ and $\rho$ the density $\left(\mathrm{kg} \mathrm{m}^{-3}\right)$.

The influence of temperature, moisture and density on the ThCond in and perpendicular to the fibre direction is described in detail by Kollmann and Côté (1968). This interrelation is approximately linear in the ranges of density 200-800 kg m${ }^{-3}$, moisture content (MC) 5\%-35\% and temperature $-50^{\circ} \mathrm{C}-100^{\circ} \mathrm{C}$.

The heat capacity is defined as the heat quantity in $\mathrm{J}$ that is required to heat $1 \mathrm{~kg}$ of a material for $1 \mathrm{~K}$ (Lohmann et al. 2003). It is strongly affected by temperature and moisture but hardly by density and therefore the wood species. According to Dunlap (1912) and Kollmann and Côté (1968), the temperature dependency of the heat capacity of oven-dry wood (mean values of 20 wood species) can be described in the following way:

$c_{o}=1114+4.86 \cdot \theta$

where $c_{o}$ is the heat capacity $\left(\mathrm{J} \mathrm{kg}^{-1} \mathrm{~K}^{-1}\right)$ and $\theta$ the temperature $\left({ }^{\circ} \mathrm{C}\right)$. Skaar (1988) listed similar values of $c_{o}$ and of the temperature dependency from further authors which confirm the measurements of Dunlap (1912). Differences to this mean heat capacity curve are mainly due to differences in lignin and cellulose content of the wood species (McMillin 1970; Hatakeyama et al. 1982; Kokta et al. 1989). Kollmann and Côté (1968) suggested a mean heat capacity value for the temperature range $0^{\circ} \mathrm{C}-100^{\circ} \mathrm{C}$, which is supposed to be useful for drying technology. This value is very high for 
application in building physics and, therefore, the heat capacity at $20^{\circ} \mathrm{C}$ presented in this study is more appropriate. According to the quoted authors, the heat capacity depending on moisture can be calculated assuming a simple additive effect of the dry wood and water:

$c_{\omega}=\frac{\omega \cdot c_{w}+c_{o}}{1+\omega}$

where $c_{\omega}$ is the heat capacity of wood $\left(\mathrm{J} \mathrm{kg}^{-1} \mathrm{~K}^{-1}\right)$ with the MC of $\omega(-), c_{w}$ is the heat capacity of water $\left(\mathrm{J} \mathrm{kg}^{-1} \mathrm{~K}^{-1}\right)$, and $c_{o}$ is the heat capacity of oven-dry wood $\left(\mathrm{J} \mathrm{kg}^{-1} \mathrm{~K}^{-1}\right)$. At MCs higher than 5\%, Eq. (3) has to be corrected due to the influence of the heat of wetting according to Kelsey and Clarke (1956) quoted in Skaar (1988):

$c_{\omega}=\left(c_{o}+\omega^{\bullet} c_{w^{-}} \frac{\partial\left(W_{o}-W\right)}{\partial T}\right) \cdot\left(\frac{1}{1+\omega}\right)$

where $W_{o}-W$ is the integral heat of wetting $\left(\mathrm{J} \mathrm{kg}^{-1}\right)$ and $T$ the temperature $(\mathrm{K})$.

The goal of the present investigation is a precise determination of the heat parameters of the two commercially important wood species, Norway spruce (Picea abies [L.] Karst.) and European beech (Fagus sylvatica L.), in all anatomical directions. Although ThCond has frequently been studied in the principal wood directions, information about ThCond of directions between the principal ones is not available from the literature. Therefore, in addition to the principal directions, ThCond was also investigated in $15^{\circ}$ steps between these directions in the present study. Owing to the anisotropic behaviour of wood at different scales, this knowledge is important to verify recent heat transport models (Perré and Turner 2001) and to optimise wood-based materials and wall constructions regarding thermal insulation. To determine the thermal diffusivity and heat capacity values, the transient method of Ghazi Wakili et al. (2003) - validated on soft fibreboards - was successfully adopted for solid wood by means of a guarded hot plate apparatus (as used to measure ThCond) which was supplemented with thermocouples.

\section{Material and methods}

\section{Material}

Dimensions of samples (made of one European beech and two Norway spruce stems from the region of Zurich): $200 \times 200 \times 20 \mathrm{~mm}^{3}$. The data were measured in the anatomical directions radial (R), tangential $(\mathrm{T})$, longitudinal $(\mathrm{L})$ and in $15^{\circ}$ steps between these directions. Accordingly, 18 variations per wood species, each of them with four specimens, were tested after reaching equilibrium $\mathrm{MC}$ at conditions $20^{\circ} \mathrm{C}$ and $65 \%$ relative humidity (RH). The specimens in the principal directions were additionally tested after being ovendried and air-conditioned at $20^{\circ} \mathrm{C}$ to $\mathrm{RHs}$ of $35 \%, 80 \%$ and $88 \%$.
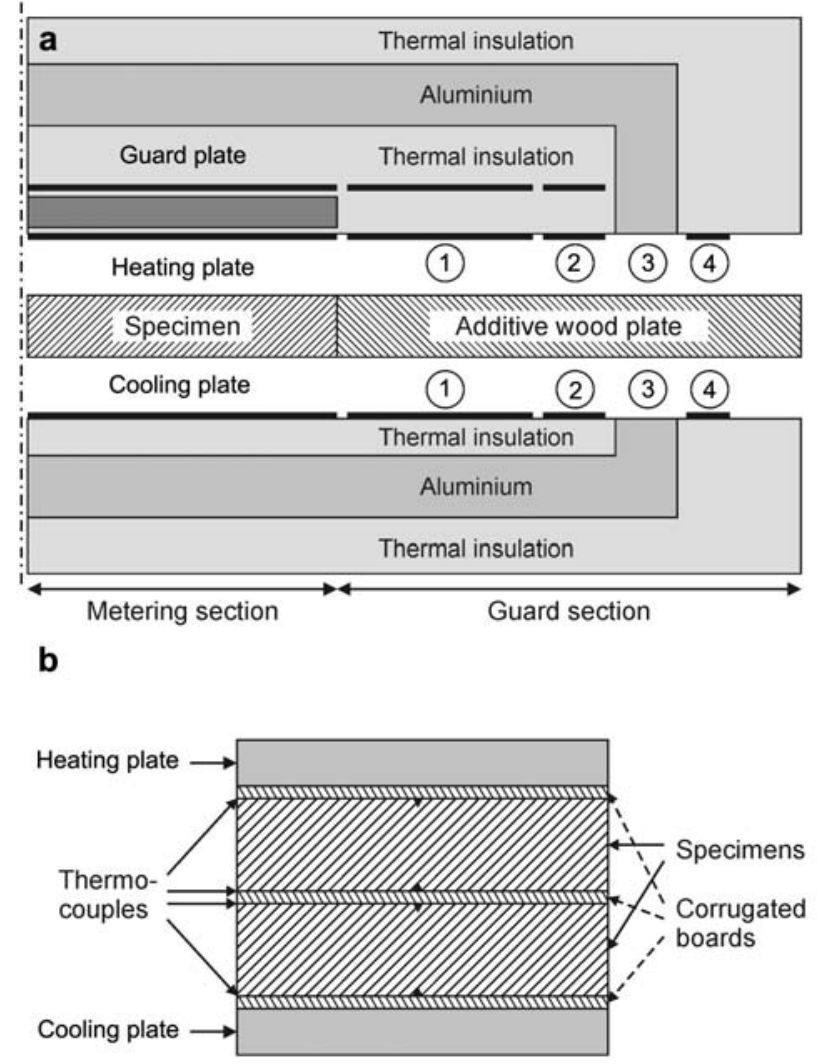

Figure 1 The experimental design. (a) The single-specimen guarded hot plate apparatus. 1, 2 and 4 are the inner, middle and external heating guard rings, respectively, and 3 the cooling ring (or tempering ring) to protect the test specimen from environmental influences. (b) Setup for measurement of the thermal diffusivity and heat capacity.

\section{Experimental setup}

Apparatus for measurement of ThCond included single-specimen guarded hot plate apparatus $\lambda$-Meter EP500 (Lambda-Messtechnik $\mathrm{GmbH}$, Dresden, Germany) according to ISO 8302 (ISO standard 1991) (Figure 1a). Sample dimensions of $500 \mathrm{~mm} \times 500 \mathrm{~mm} \times$ sample thickness are usual and the measurement is conducted circularly with a diameter of $200 \mathrm{~mm}$ in the middle of the sample. The outer parts serve as protection from environmental influences. As in the present case, the samples had only dimensions of approximately $200 \mathrm{~mm} \times 200 \mathrm{~mm}$, they were placed centrally on the plate and the brims were covered with wood plates of similar fibre orientation and thicknesses so that the whole area simulated the standard conditions $\left(500 \times 500 \mathrm{~mm}^{2}\right)$.

The thermal conductivities were measured at $10^{\circ} \mathrm{C}, 20^{\circ} \mathrm{C}$ and $30^{\circ} \mathrm{C}$. In the case of spruce, the temperatures between the radial and tangential direction were $10^{\circ} \mathrm{C}, 25^{\circ} \mathrm{C}$ and $40^{\circ} \mathrm{C}$. The temperature difference between the heating and the cooling plate was of $5^{\circ} \mathrm{C}$ and $10^{\circ} \mathrm{C}$, respectively, to measure parallel and perpendicular to the fibre direction. From the values at the three temperatures, the ThCond was determined by a linear regression. The slope of the regression line corresponds to the temperature coefficient of the ThCond.

The thermal diffusivity and heat capacity were only measured in the three main directions under the same $\mathrm{RH}$ conditions as used to measure the ThCond. Thermocouples were installed to make the equipment suitable for measurements for thermal diffusivity and 


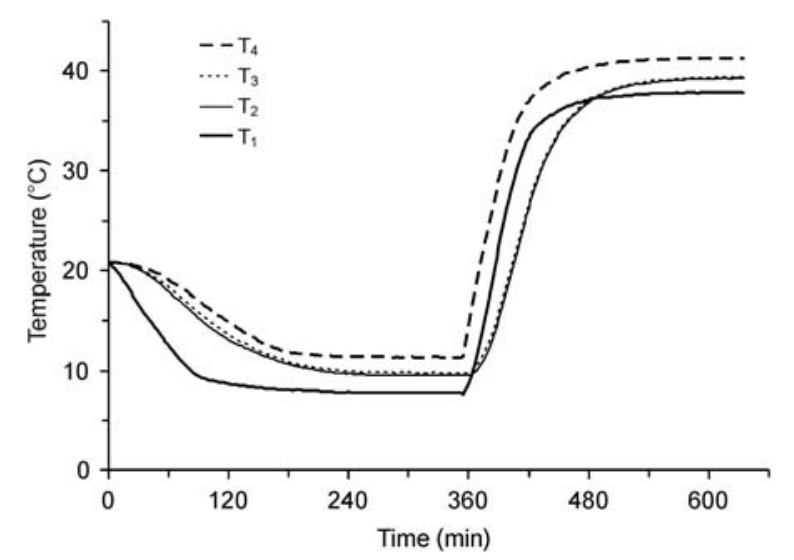

Figure 2 Temperature profiles during a test period (Norway spruce, tangential direction, $80 \% \mathrm{RH}$ ). $\mathrm{T}_{1}, \mathrm{~T}_{2}$ : lower and upper thermocouples of the lower specimen; $\mathrm{T}_{3}, \mathrm{~T}_{4}$ : lower and upper thermocouples of the upper specimen.

heat capacity. Two specimens were measured simultaneously with at least two thermocouples on the upper and lower side of each specimen. To protect the thermocouples, a thin corrugated board was placed between the two specimens as well as between the specimens and the cooling and the heating plate, respectively (Figure 1b).

\section{Thermal diffusivity and heat capacity}

For the tests, the smallest available temperature difference of $5^{\circ} \mathrm{C}$ between the heating and the cooling plate was used. Starting at the initial condition of approximately $20^{\circ} \mathrm{C}$, the plates were first cooled to a mean temperature of $10^{\circ} \mathrm{C}$ and then heated to a mean temperature of $40^{\circ} \mathrm{C}$. Figure 2 shows the temperature profiles of such a test period.

From the measured temperature profiles, the thermal diffusivity in the direction perpendicular to the plates, i.e., in the $\mathrm{R}, \mathrm{T}$ and $\mathrm{L}$ direction of the specimens, was determined by means of the $1 \mathrm{D}$ heat equation in the form of a second order linear partial differential equation $(P D E)$ :

$\frac{\partial \theta}{\partial t}=\frac{\partial}{\partial x}\left(\alpha \frac{\partial \theta}{\partial x}\right)$

where $\theta$ is the temperature, $t$ the time, $x$ the direction of heat flux $(\mathrm{R}, \mathrm{T}$ and $\mathrm{L})$ and $\alpha$ the thermal diffusivity.
The initial temperature in the calculation was obtained from the experimental data. Thus, Eq. (5) could be solved (MATLAB ${ }^{\circledR}$ solver algorithm for partial differential equations) under the conditions of lower [Eq. (6)] and upper boundaries [Eq. (7)]:

$\theta(0, t)=T_{1}(t)$

$\theta(b, t)=T_{4}(t)$

where $T_{1}$ is the mean temperature profile of the thermocouples at the lower side of the lower specimen, $T_{4}$ is the same at the upper side of the upper specimen and $b$ the height between the thermocouples of $T_{1}$ and $T_{4}$. Differences between the experimental results $\theta_{\text {exp }}$ and the results for the solved PDE $\theta_{\text {calc }}$ were characterised by an objective function $S$ :

$S=\sum_{i=1}^{n} \sum_{j=1}^{m}\left(\theta_{\exp }\left(x_{i}, t_{j}\right)-\theta_{\text {calc }}\left(x_{i}, t_{j}\right)\right)^{2}$

where $n$ is the number of the inner temperature measurement points $\left(T_{2}, T_{3}\right)$ and $m$ is the number of time steps. The corresponding analysis parameter $\alpha$ was yielded by minimising $S$ by means of the 'Nelder-Mead simplex direct search' optimisation algorithm (Nelder and Mead 1965).

The heat capacity was calculated according to Eq. (1) based on the ThCond determined by the diffusivity test. It is evaluated under the assumption of steady-state conditions where an identical heat flow rate in each layer exists (Hens 2007), as follows:

$\lambda_{T}=\frac{d_{1}+d_{2}}{R_{\text {all }} \cdot \frac{\Delta T_{w}}{\Delta T_{\text {all }}}}$

where $\lambda_{T}$ is the ThCond $\left(\mathrm{W} \mathrm{m}^{-1} \mathrm{~K}^{-1}\right)$ of the specimens at temperatures of $10^{\circ} \mathrm{C}$ and $40^{\circ} \mathrm{C}, d_{1}$ and $d_{2}$ are the thicknesses (m) of the lower and upper specimen, respectively (Figure 1b), $R_{\text {all }}$ is the thermal resistance $\left(\mathrm{m}^{2} \mathrm{~K} \mathrm{~W}^{-1}\right)$, measured with the guarded hot plate apparatus at the same temperatures over the whole formation, $\Delta T_{w}$ is the temperature difference $\left({ }^{\circ} \mathrm{C}\right)$ of the two specimens $\left(T_{2}-T_{1}+T_{4^{-}}\right.$ $T_{3}$ ) at steady-state conditions (i.e., at mean temperatures of $10^{\circ} \mathrm{C}$ and $40^{\circ} \mathrm{C}$; Figure 2) and $\Delta T_{\text {all }}$ is the temperature difference $\left({ }^{\circ} \mathrm{C}\right)$ over the whole formation.

Table 1 Parameters of the function $\lambda=A+B \cdot \omega$ describing the thermal conductivity $(\lambda)$ depending on MC $(\omega)$ and the equilibrium MCs at which the experimental data were collected (in parentheses: temperature in ${ }^{\circ} \mathrm{C} / \mathrm{relative}$ humidity in $\%)^{\mathrm{a}}$.

\begin{tabular}{cccccccccc}
\hline \multirow{2}{*}{$\begin{array}{c}\text { Wood } \\
\text { species }\end{array}$} & Direction & $\begin{array}{c}\text { Air-dry } \\
\text { density } \\
\left(\mathrm{kg} \mathrm{m}^{-3}\right)\end{array}$ & $\begin{array}{c}\omega \\
(20 / 35) \\
(\%)\end{array}$ & $\begin{array}{c}\omega \\
(20 / 65) \\
(\%)\end{array}$ & $\begin{array}{c}\omega \\
(20 / 80) \\
(\%)\end{array}$ & $\begin{array}{c}\omega \\
(20 / 88) \\
(\%)\end{array}$ & $\begin{array}{c}A\left(=\lambda_{10 . \text { dry }}\right) \\
\left(\mathrm{W} \mathrm{m}^{-1} \mathrm{~K}^{-1}\right)\end{array}$ & $\begin{array}{c}B\left(=\Delta \lambda_{\omega}\right) \\
\left(\mathrm{W} \mathrm{m}^{-1} \mathrm{~K}^{-1}\right)\end{array}$ & $\mathrm{R}^{2}$ \\
\hline Norway spruce & $\mathrm{R}$ & 446 & 8.9 & 14.3 & 16.4 & 19.2 & 0.086 & $1.08 \times 10^{-3}$ & 0.97 \\
& $\mathrm{~T}$ & 410 & 8.9 & 14.3 & 16.9 & 19.7 & 0.071 & $1.28 \times 10^{-3}$ & 0.999 \\
& $\mathrm{~L}$ & 425 & 8.8 & 14.4 & 16.8 & 19.4 & 0.223 & $0.44 \times 10^{-3}$ & 0.37 \\
European beech & $\mathrm{R}$ & 640 & 8.3 & 14.0 & 16.2 & 18.6 & 0.120 & $1.93 \times 10^{-3}$ & 0.95 \\
& $\mathrm{~T}$ & 682 & 8.4 & 13.9 & 16.0 & 18.8 & 0.092 & $2.35 \times 10^{-3}$ & 0.96 \\
& $\mathrm{~L}$ & 674 & 8.3 & 14.1 & 16.5 & 18.9 & 0.257 & $0.31 \times 10^{-3}$ & 0.06 \\
\hline
\end{tabular}

${ }^{\mathrm{a}} A=\lambda_{10 . \text { dry }}\left(\lambda\right.$ at oven-dry condition and $\left.10^{\circ} \mathrm{C}\right), B=\Delta \lambda_{\omega}$ (change of $\lambda$ per percent $\mathrm{MC}$ ), $\mathrm{R}=$ radial, $\mathrm{T}=$ tangential, $\mathrm{L}=$ longitudinal, $\mathrm{R}^{2}=$ coefficient of determination. 
Table 2 Parameters of the polynomial function $\lambda=A+B \cdot x+C \cdot x^{2}+D \cdot x^{3}$ describing the thermal conductivity between the principal directions of spruce and beech.

\begin{tabular}{ccccccc}
\hline $\begin{array}{c}\text { Wood } \\
\text { species }\end{array}$ & Direction & $A$ & $B$ & $C$ & $D$ & $\mathrm{R}^{2}$ \\
\hline Norway spruce & $\mathrm{L}-\mathrm{R}$ & 0.234 & $-5.84 \times 10^{-4}$ & $-3.58 \times 10^{-5}$ & $2.88 \times 10^{-7}$ & 0.998 \\
& $\mathrm{~L}-\mathrm{T}$ & 0.235 & $1.87 \times 10^{-4}$ & $-5.66 \times 10^{-5}$ & $4.10 \times 10^{-7}$ & 0.999 \\
& $\mathrm{~T}-\mathrm{R}$ & 0.093 & $1.80 \times 10^{-4}$ & $-7.96 \times 10^{-6}$ & $7.99 \times 10^{-8}$ & 0.75 \\
European beech & $\mathrm{L}-\mathrm{R}$ & 0.251 & $1.18 \times 10^{-3}$ & $-6.15 \times 10^{-5}$ & $4.06 \times 10^{-7}$ & 0.99 \\
& $\mathrm{~L}-\mathrm{T}$ & 0.250 & $1.50 \times 10^{-3}$ & $-7.51 \times 10^{-5}$ & $4.78 \times 10^{-7}$ & 0.99 \\
& $\mathrm{~T}-\mathrm{R}$ & 0.127 & $4.41 \times 10^{-5}$ & $1.15 \times 10^{-5}$ & $-9.59 \times 10^{-8}$ & 0.95 \\
\hline
\end{tabular}

$\mathrm{L}=$ longitudinal, $\mathrm{R}=$ radial, $\mathrm{T}=$ tangential, $\mathrm{R}^{2}=$ coefficient of determination.

\section{Results and discussion}

\section{General remarks}

The data in Tables 1 and 2 and Figures 3-6 represent the mean values of the measured samples or are deduced from them. For the thermal conductivity (ThCond), the variation within the four specimens measured per type highly depended on density. Thus, the particular variation coefficient within a type varied between $0.1 \%$ and $4.5 \%$. To determine the thermal diffusivity and heat capacity, in each case two specimens were measured simultaneously resulting in only two independent measurements per type. The variation between both measurements was in the same order of magnitude as that of the ThCond.

\section{Thermal conductivity}

The ThCond of Norway spruce and European beech at $10^{\circ} \mathrm{C}$ in the three principal anatomical directions depending on $\mathrm{MC}$ are presented in Table 1 and Figure 3. For both wood species, the thermal conductivities in the $\mathrm{L}$ direction are more than twice as high as in the directions perpendicular to the grain, and clearly higher in the $\mathrm{R}$ than in the $\mathrm{T}$ direction.

For beech wood, the moisture-dependant gradients of ThCond are nearly twice as high than for spruce wood in the $\mathrm{R}$ and $\mathrm{T}$ directions, and are higher in the $\mathrm{T}$ than in the $\mathrm{R}$ direction for both species. This is due to the increase of density with increasing MC on the one hand, which - in

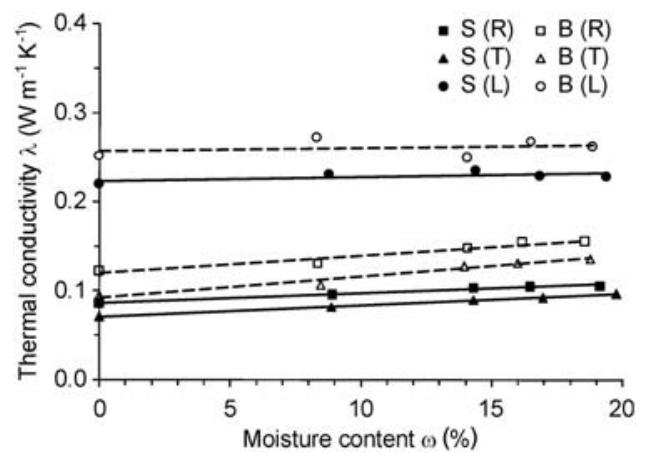

Figure 3 Linear correlation of thermal conductivity $(\lambda)$ of Norway spruce (S) and European beech (B) in the radial (R), tangential (T) and longitudinal (L) directions as a function of moisture content $(\omega)$. absolute values - is higher for beech than for spruce. On the other hand, the main reason is a clearly higher ThCond of water (approximately $0.60 \mathrm{~W} \mathrm{~m}^{-1} \mathrm{~K}^{-1}$ ) compared to wood, which influences the generally lower values in the $\mathrm{T}$ direction stronger than those in the $\mathrm{R}$ direction. By contrast, the moisture-dependant gradient in the $\mathrm{L}$ direction is very low for both species. For elm wood (Ulmus scabra Mill.), Hrčka and Kurjatko (2006) also found only a small correlation between ThCond and $\mathrm{MC}$ in the $\mathrm{L}$ direction. This partly results from a high variation of the values in this direction (cf. the low coefficient of determination, $\mathrm{R}^{2}$, in Table 1). Otherwise, this finding can be attributed to the generally higher ThCond of the net cell wall substance in this direction $\left(0.65 \mathrm{~W} \mathrm{~m}^{-1} \mathrm{~K}^{-1}\right)$, which is similar to the ThCond of water (Maku 1954; Siau 1995). Therefore, the ThCond is only
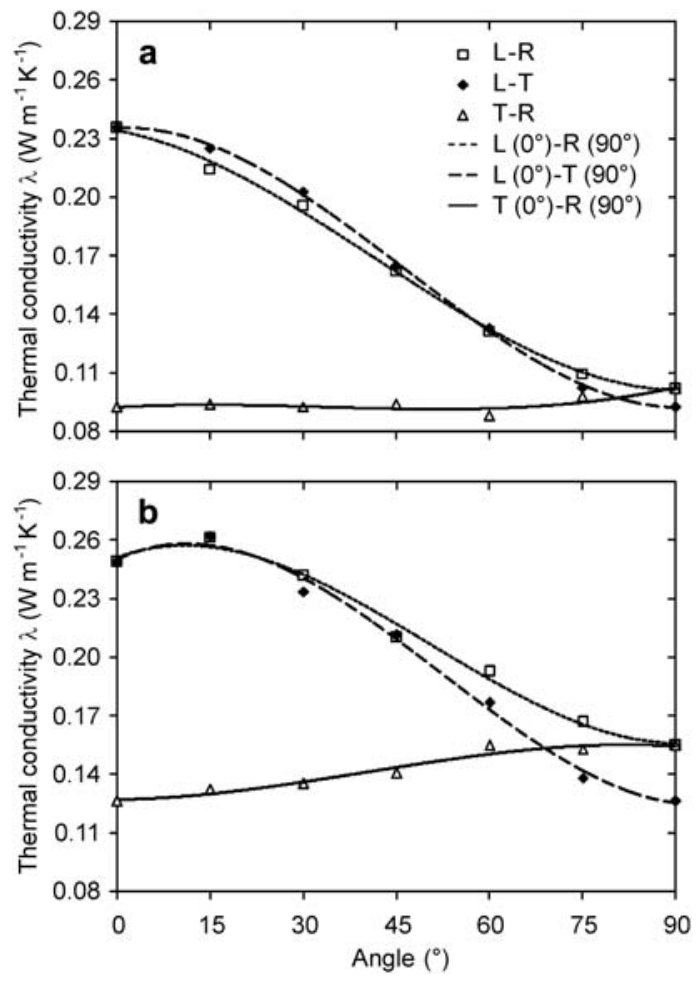

Figure 4 Thermal conductivity $(\lambda)$ at $10^{\circ} \mathrm{C}$ in and between the principal anatomical directions of Norway spruce (a) and European beech (b) previously conditioned at $20^{\circ} \mathrm{C}$ and $65 \% \mathrm{RH} . \mathrm{R}=$ radial, $\mathrm{T}=$ tangential, $\mathrm{L}=$ longitudinal. 

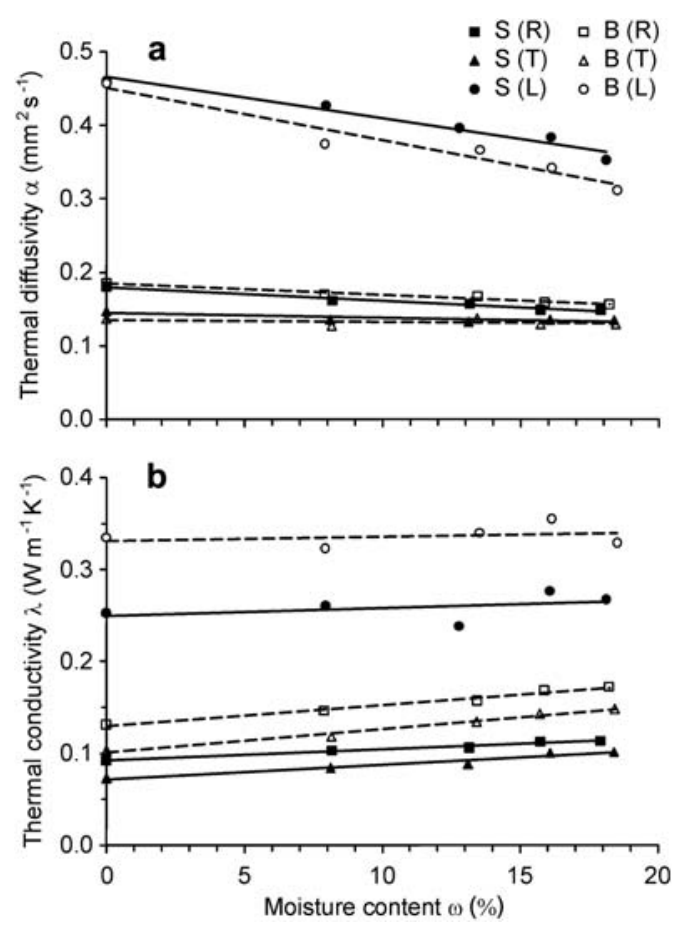

Figure 5 (a) Thermal diffusivity $(\alpha)$ and (b) corrected thermal conductivity $(\lambda)$ of Norway spruce (S) and European beech (B) in the anatomical directions radial (R), tangential (T) and longitudinal $(\mathrm{L})$ as a function of moisture content $(\omega)$.

influenced by the change in density with increasing MC. This influence of the MC would be diminished further if it were taken into account that the ThCond of bound water is even lower than that of free water (MacLean 1941).

The mean temperature coefficient of the ThCond perpendicular to the fibre results in $0.22 \%{ }^{\circ} \mathrm{C}^{-1}$ for spruce and $0.25 \%{ }^{\circ} \mathrm{C}^{-1}$ for beech, and both are in good agreement with values obtained by Kühlmann (1962), Steinhagen (1977) and Suleiman et al. (1999). The temperature coefficient parallel to the fibre $\left(0.39 \%{ }^{\circ} \mathrm{C}^{-1}\right)$ is clearly higher for both species than it is perpendicular to the fibre. This is in contrast to the measurements of Suleiman et al. (1999), who measured lower temperature coefficients parallel to the fibre rather than perpendicular. The differences could be due to the different temperature ranges and measuring methods applied and needs further clarification.

Figure 4 shows the run of the curves of the ThCond between the three principal anatomical directions for Norway spruce and European beech. Owing to a high variability of the sample densities in the different directions, the thermal conductivities were corrected to a mean uniform density of $427 \mathrm{~kg} \mathrm{~m}^{-3}$ for spruce and $673 \mathrm{~kg} \mathrm{~m}^{-3}$ for beech wood to increase the comparability between the data measured for the different directions by the following equation:

$\lambda_{\text {cor }}=\lambda_{\text {meas }}+\left(\frac{\lambda_{\text {meas }}-\lambda_{\text {air }}}{\rho_{\text {meas }}}\right)\left(\rho_{\text {cor }}-\rho_{\text {meas }}\right)$

where $\lambda_{c o r}$ is the ThCond corrected to a uniform density, $\lambda_{\text {meas }}$ is the measured ThCond of the sample, $\lambda_{\text {air }}$ is the
ThCond of the air $\left(=0.026 \mathrm{~W} \mathrm{~m}^{-1} \mathrm{~K}^{-1}\right), \rho_{\text {cor }}$ is the uniform density and $\rho_{\text {meas }}$ is the measured density of the sample.

The gradient between two main directions was then determined as a polynomial function of third degree (Figure 4). The parameters are presented in Table 2. Perpendicular to the grain, the ThCond of beech increases slightly with increasing ring angle (angle between the $\mathrm{T}$ and the $\mathrm{R}$ direction), whereas the ThCond of spruce has the lowest value on a ring angle of $60^{\circ}$. This could be due to the different anatomical compositions of the two species. Whereas the density within an annual ring of beech varies only slightly, the densities of earlywood and latewood of spruce differ by a factor of three so that it has some similarity to a layered material. Thus, without the influence of the rays, the ThCond in the $\mathrm{R}$ direction would be clearly lower than in the $\mathrm{T}$ direction (analogous to connection in series and that in parallel). This means for a ring angle of $60^{\circ}$ that there is still a considerable influence of the earlywood and latewood layers, which reduces the ThCond, although the influence of the rays has already decreased. Moreover, as a result of the misalignment of the cells in the $\mathrm{T}$ direction, the longest way along the cell walls - at least in the earlywood - could be stated for spruce at a ring angle of approximately $60^{\circ}$.

From the directions perpendicular to the grain ( $\mathrm{R}$ and $\mathrm{T}$ ) to the $\mathrm{L}$ direction, the highest gradient of ThCond was found between a grain angle of $15^{\circ}$ and $75^{\circ}$ for both species. Whereas the highest ThCond for spruce was measured in the $\mathrm{L}$ direction, for beech it was found at a grain angle of $15^{\circ}$. This is assumed to be influenced by a high microfibril angle (MFA) in the S2 layers of the cell walls because the cellulose favours the heat transport along their molecular chains (Kollmann and Malmquist 1956). A high MFA is described for beech in the literature. For instance, Bucur (1986) measured a mean MFA of $18^{\circ}$ in normal beech wood and Lehringer et al. (2009) reported an MFA between $32^{\circ}$ and $39.8^{\circ}$ for tension wood and opposite wood. By contrast, Keunecke and Niemz (2008) and Keunecke et al. (2009) measured a mean MFA of approximately $10^{\circ}$ for spruce wood, although the

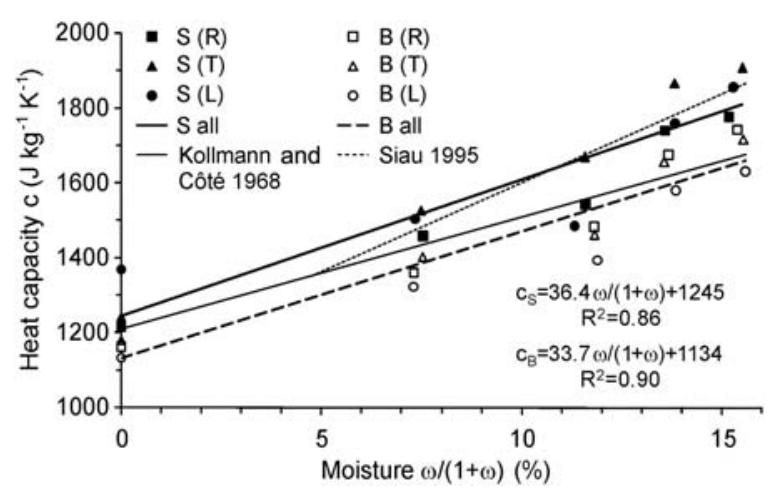

Figure 6 Heat capacity (c) of Norway spruce (S) and European beech (B) determined in the radial (R), tangential (T) and longitudinal (L) directions as a function of moisture content $\omega(-)$. Regression curves are averaged over all three directions ( $\mathrm{S}$ all, B all) and for comparison data of Kollmann and Côté (1968) according to Eq. (3) and Siau (1995) according to Eq. (4) are included. 
data varies in a wide range concerning the whole stem (Brändström 2001).

\section{Thermal diffusivity and heat capacity}

The thermal diffusivities depending on MC for spruce and beech in the three principal anatomical directions are shown in Figure 5a. Analogous to the ThCond, the highest diffusivity was measured in the $\mathrm{L}$ direction followed by the $\mathrm{R}$ and $\mathrm{T}$ directions. However, in contrast to the ThCond, the diffusivity decreases with increasing MC. This was also stated by Kühlmann (1962) and Steinhagen (1977) who analysed data from diverse authors. Thereby, the highest decrease occurs in the L direction, whereas diffusivity in the T direction runs nearly at a constant level. Values similar to those for the $\mathrm{L}$ direction of beech wood have been determined by Hrčka and Kurjatko (2006) for elm wood.

The heat capacities shown in Figure 6 were calculated from the thermal diffusivities determined according to Eqs. (5) to (8) and the ThConds determined according to Eq. (9) for a temperature of $20^{\circ} \mathrm{C}$. Therefore, the heat capacity of beech was approximately $10 \%$ lower than that of spruce. This could be due to different amounts of lignin and amorphous and crystalline cellulose (Wagenführ 2007), which according to Hatakeyama et al. (1982) clearly differ in their heat capacities being higher for lignin and amorphous cellulose than for crystalline cellulose. This seems to be reasonable, although Kokta et al. (1989) measured decreasing heat capacities with increasing lignin content on high-yield bisulphite wood pulp and McMillin (1970) showed only minor differences in the values for lignin and cellulose.

The heat capacities of both species increase with increasing MC. In addition, comparative values from the literature are shown in Figure 6. The curve demonstrated by Kollmann and Côté (1968) shows the moisture-dependant heat capacity [based on values of Dunlap (1912) at $20^{\circ} \mathrm{C}$ according to Eq. (2)] taking only the additive effect of dry wood and of water [see Eq. (3)] into account. The curve is arranged between the values of spruce and beech and, as expected, the gradient is lower than the linear trend of the measured data due to the heat of wetting, which was not included into the calculation. In the curve of Siau (1995), the heat of wetting is considered [(Eq. (4)] using values of Kelsey and Clarke (1956). It shows reasonable agreement with the values measured for spruce.

The thermal conductivities determined according to Eq. (9) were significantly higher than the values measured directly with the guarded hot plate apparatus and are depicted in Figure $5 \mathrm{~b}$. The mean increases of the values perpendicular to the grain were approximately $6 \%$ for spruce and $9 \%$ for beech, whereas in the $\mathrm{L}$ direction the mean increases were approximately $14 \%$ for spruce and $29 \%$ for beech. This finding could be attributed to a shorter steady-state time period and a lower temperature gradient that were used for the determination of the thermal diffusivity, or, on the contact resistance between the specimen and the heating and the cooling plates (Bučar and Straže 2008).

\section{Conclusions}

The ThCond was investigated in and between the three principal anatomical directions of Norway spruce and European beech. The highest ThCond was determined to be in the $\mathrm{L}$ direction for spruce, whereas beech had the highest ThCond at a grain angle of approximately $15^{\circ}$. This could be explained by the different MFAs in the S2 layers of these trees. Although the lowest ThCond was determined for beech in the $\mathrm{T}$ direction, the same data for spruce was found at a ring angle of approximately $60^{\circ}$. This could be due to the different portions of wood rays and the arrangement of the cells. The influence of the MC on the ThCond is higher in the $\mathrm{T}$ than in the $\mathrm{R}$ direction and very low in fibre direction. The transient method used to detect the heat capacity yielded results in good agreement with those of previous measurements already stated by Ghazi Wakili et al. (2003). All these findings could serve to optimise wood construction with regard to its use as an insulating material.

\section{References}

Brändström, J. (2001) Micro- and ultrastructural aspects of Norway spruce tracheids: a review. IAWA J. 22:333-353.

Bucur, V. (1986) Mesures sur carottes de sondage de quelques propriétés physiques de bois de hêtre à fortes contraintes de croissance. Ann. Sci. For. 43:115-124.

Bučar, B., Straže, A. (2008) Determination of the thermal conductivity of wood by the hot plate method: the influence of morphological properties of fir wood (Abies alba Mill.) to the contact thermal resistance. Holzforschung 62:362-367.

Dunlap, F. (1912) The specific heat of wood. Forest Products Laboratory, Bulletin 110, U.S. Department of Agriculture. Forest Service, Madison, WI.

Ghazi Wakili, K., Binder, B., Vonbank, R. (2003) A simple method to determine the specific heat capacity of thermal insulations used in building construction. Energ. Buildings 35:413-415.

Hatakeyama, T., Nakamura, K., Hatakeyama, H. (1982) Studies on heat capacity of cellulose and lignin by differential scanning calorimetry. Polymer 23:1801-1804.

Hens, H. (2007) Building Physics - Heat, Air and Moisture. Ernst \& Sohn, Berlin.

Hrčka, R., Kurjatko, S. (2006) Thermal properties of elm wood (Ulmus scabra Mill.). In: Wood Structure and Properties '06. Eds. Kurjatko, S., Kudela, J., Lagana, R. Arbora Publishers, Zvolen. pp. 245-249.

ISO standard (1991) ISO 8302. Thermal insulation - Determination of steady-state thermal resistance and related properties - Guarded hot plate apparatus.

Kelsey, K.E., Clarke, L.N. (1956) The heat of sorption of water by wood. Aust. J. Appl. Sci. 7:160-175.

Keunecke, D., Niemz, P. (2008) Axial stiffness and selected structural properties of yew and spruce microtensile specimens. Wood Res. 53:1-14.

Keunecke, D., Evans, R., Niemz, P. (2009) Microstructural properties of common yew and Norway spruce determined with SilviScan. IAWA J. 30:165-178.

Kokta, B.V., Maldas, D., Kuruvilla, A. (1989) The effect of pulping techniques and lignin content on the specific heat capacity of wood pulp. Tappi J. 72:177-178. 
Kollmann, F., Côté, W.A., Jr. (1968) Principles of Wood Science and Technology. Vol. I: Solid Wood. Springer-Verlag, Berlin.

Kollmann, F., Malmquist, L. (1956) Über die Wärmeleitzahl von Holz und Holzwerkstoffen. Holz Roh Werkst. 14:201-204.

Kühlmann, G. (1962) Untersuchung der thermischen Eigenschaften von Holz und Spanplatten in Abhängigkeit von Feuchtigkeit und Temperatur im hygroskopischen Bereich. Holz Roh Werkst. 20:259-270.

Lehringer, C., Daniel, G., Schmitt, U. (2009) TEM/FE-SEM studies on tension wood fibres of Acer spp., Fagus sylvatica L. and Quercus robur L. Wood Sci. Technol. 43:691-702.

Lohmann, U., Blosen, M., Boehm., et al. (2003) Holz-Lexikon. Vol. 2, 4th edn. DRW-Verlag, Leinfelden-Echterdingen.

MacLean, J.D. (1941) Thermal conductivity of wood. Heat Piping Air Cond. 13:380-391.

Maku, T. (1954) Studies on the heat conduction in wood. 'Wood Research' Bulletin of the Wood Research Institute, No. 13, Kyoto University, Kyoto, Japan.

McMillin, W. (1970) Specific heat of some oven-dry chemical constituents of Loblolly pine wood. Wood Sci. 3:52-53.

Nelder, J.A., Mead, R. (1965) A simplex method for function minimization. Comput. J. 7:308-313.
Perré, P., Turner, I. (2001) Determination of the material property variations across the growth ring of softwood for use in a heterogeneous drying model. Part 2. Use of homogenisation to predict bound liquid diffusivity and thermal conductivity. Holzforschung 55:417-425.

Siau, J.F. (1995) Wood: Influence of Moisture on Physical Properties. Virginia Polytechnic Institute and State University, Keene, NY.

Skaar, C. (1988) Wood-Water Relations. Springer-Verlag, Berlin.

Steinhagen, H.P. (1977) Thermal conductive properties of wood, green or dry, from $-40^{\circ}$ to $+100^{\circ} \mathrm{C}$ : a literature review. Forest Products Laboratory, U.S. Department of Agriculture, Forest Service, Madison, WI.

Suleiman, B.M., Larfeldt, J., Leckner, B., Gustavsson, M. (1999) Thermal conductivity and diffusivity of wood. Wood Sci. Technol. 33:465-473.

Wagenführ, R. (2007) Holzatlas. 6th edn. Fachbuchverlag, Leipzig.

Received July 20, 2010. Accepted November 11, 2010. Previously published online February 7, 2011. 